\title{
Towards a Typology of Cross-Channel Dramatic Borrowings: The View from the White Cliffs
}

\author{
RICHARD HILLMAN \\ Centre d'Études Supérieures de la Renaissance (Université François-Rabelais \\ de Tours/CNRS)
}

Scholarship on the diverse ways in which early modern English playwrights "translated" French textual material, dramatic and otherwise, has by now accumulated enough specific instances to justify an overview of methods and results. There are few outright translations of French plays, but the field widens considerably when adaptations and appropriations of various kinds are added to the picture. It then becomes possible to identify a variety of intertextual experiences that implicate audiences in issues of genre, religion, and politics.

Les recherches sur les différentes approches avec lesquelles les dramaturges anglais des débuts de la modernité ont " traduit » des œuvres littéraires françaises de tous genres, ont accumulé suffisamment détudes de cas pour permettre un examen global de leurs méthodes et des résultats correspondants. On trouve en réalité peu de traductions intégrales de pièces de théâtre de langue française, mais le corpus sélargit considérablement lorsqu'on tient compte des adaptations et des appropriations textuelles de différentes sortes. Cela devient alors possible d'identifier une variété d'effets intertextuels engageant spectateurs et lecteurs dans des questions du genre, de la religion et de la politique.

$\mathrm{T}$ he simple premise of this article is that the diverse ways in which early modern English playwrights responded to French cultural material, dramatic and otherwise, deserve to be identified and classified. (For practical reasons, the perspective will be applied in one direction only.) We have accumulated enough specific points of contact to justify attempting a systematic overview and a division into categories; it now seems possible to define certain types of transmission and to associate these with particular kinds of dramatic purposes, practices, and results.

This is not, at least primarily-and certainly not theoretically-a matter of establishing influences. For we have also, I would like to think, wriggled out of the straitjacket of traditional source-and-influence thinking. This liberation may, however, seem intimidating-hence, perhaps, the impulse to seek comfort in familiar ways of documenting concrete parallels and contrasts, or, at the other extreme, to assimilate a wide range of early modern English responses to slightly varied models of ambivalence. The earliest explorations 
of French elements within, or in relation to, English drama were dominated by topical allusion-hunting. ${ }^{1}$ Currently, the idea that the English were at once drawn to and repelled by aspects of French culture, society, and politics has effectively taken over as a blanket approach to English literary-including dramatic - re-figurations of French subject matter. On this basis one may group together, despite divergences on particulars, the essential work of Andrew M. Kirk, Deanne Williams, Michael Saenger, and others-including myself. ${ }^{2}$ The present article, by contrast, seeks to look under the theoretical blanket, as it were; its approach and objectives are empirical—and modest. I propose merely to pinpoint some of the French-to-English configurations to which the term "translation," in various senses, might apply. I hope, in addition, that defining these may stake out areas for further exploration.

The obvious starting point, given the theme, is the paucity of outright translations into English of French plays published prior to 1637, ${ }^{3}$ and the fact that none of these seems to have reached, or been intended for, the English stage, at least not the public one. We can count, as far as I know, only Arthur

1. A venerable example of the allusion-hunting school is Percy Allen, The Plays of Shakespeare and Chapman in Relation to French History, intro. Marjory Bowen (London: Archer, 1933). The tendency is still evident, albeit with a New Historicist twist: see, for example, Lisa Hopkins, "Paris Is Worth a Mass: All's Well That Ends Well and the Wars of Religion," in Shakespeare and the Culture of Christianity in Early Modern England, ed. Dennis Taylor and David N. Beauregard (New York: Fordham University Press, 2003), 369-81, and Richard Wilson, “'Worthies away': The Scene Begins to Cloud in Shakespeare's Navarre," in Representing France and the French in Early Modern English Drama, ed. Jean-Christophe Mayer (Newark: University of Delaware Press, 2008), 93-109.

2. See, notably, Andrew M. Kirk, The Mirror of Confusion: The Representation of French History in English Renaissance Drama, Garland Reference Library of the Humanities 1928, Garland Studies in the Renaissance 6 (New York: Garland, 1996); Deanne Williams, The French Fetish from Chaucer to Shakespeare, Cambridge Studies in Renaissance Literature and Culture (Cambridge: Cambridge University Press, 2004); Michael Saenger, Shakespeare and the French Borders of English (New York: Palgrave Macmillan, 2013). As for my own work, I will be citing it throughout to indicate where specific points are developed more fully in relation to existing criticism.

3. In this year, on the threshold of major theatrical changes on both sides of the Channel, and new forms of exchange, appeared Pierre Corneille, The Cid, a tragicomedy, out of French made English: and acted before their Majesties at court, and on the Cock-pit stage in Drury-lane by the servants to both their Majesties (London: John Haviland for Thomas Walkly, 1637), translated by Joseph Rutter. 
Golding's Abraham's Sacrifice (from the Abraham sacrifiant [1550] of Théodore de Bèze), published in 1577 by the resolutely Huguenot publisher Thomas Vautrollier, and the renditions of Robert Garnier's Marc Antoine and Cornélie (1593-54) by, respectively, Mary Sidney Herbert, Countess of Pembroke and Thomas Kyd. (The latter never got around to the translation of Garnier's Porcie that he had promised his dedicatee, the Countess of Sussex.)

The scarcity of translated play-texts and their seeming confinement to readers, rather than spectators, are hardly unique to French originals, and indeed are hardly surprising, given the abundance of "native" dramatic material (including forms of adaptation) and the exuberant practices and expectations of the early modern English theatre. At the same time, this trio of French dramatic translations reveals ideological concerns and points of sensitivity. Most obviously, De Bèze's Protestant adaptation of a traditional biblical mystery matches the Puritan orientation of Golding, who virtually announced his far more famous translation of the Metamorphoses as an act of appropriation and containment of pagan myth. ${ }^{4}$ Appropriation and containment may apply as well, as I have argued at length elsewhere, to Mary Sidney Herbert's translation on both religious and moral levels, with the aid, for the first publication, of its companion piece, Philippe de Mornay's A Discourse of Life and Death. ${ }^{5}$ The effect is less pervasive and insistent in Kyd's Cornelia, where Garnier's recreation of paganism was less susceptible to be read as slipping into Catholic-tinged immorality, but Kyd planted at least one signpost easily legible to his readership: he demonstrably altered his original's account of Caesar's assassination so as to evoke that of the Admiral Coligny during the Saint Bartholomew's massacre of 1572. ${ }^{6}$ Taken together, then, our three complete and avowed translations of French plays form a Protestant phalanx, and a defensive one.

4. Richard Hillman, "Dieu et les dieux dans l'Abraham sacrifiant de Théodore de Bèze et sa traduction anglaise par Arthur Golding," in Dieu et les dieux dans le théâtre de la Renaissance: actes du XLV colloque international d'Études humanistes, 01-06 juillet 2002, ed. Jean-Pierre Bordier and André Lascombes (Turnhout: Brepols, 2006), 225-34, 232-33.

5. Richard Hillman, "De-centring the Countess's Circle: Mary Sidney Herbert and Cleopatra," Renaissance and Reformation/Renaissance et Réforme 28.1 (2004): 61-79, and French Reflections in the Shakespearean Tragic: Three Case Studies (Manchester: Manchester University Press, 2012), 122-38.

6. See François de Chantelouve, The Tragedy of the Late Gaspard de Coligny and Pierre Matthieu, The Guisiade, ed. and trans. Richard Hillman, Carleton Renaissance Plays in Translation 40 (Ottawa: Dovehouse Editions, 2005), 44-45. 
When we widen the field of "translating for the stage" to partial and oblique adaptations and allusions of various kinds, the religious factor tends to fade in prominence, if not necessarily in significance, which is far from the same thing. At the same time, the implications for genre become more conspicuous. The generic question comes into focus as early as John Heywood's Johan Johan (1520), which, in reworking the anonymous Farce $d u$ pasté, appropriates a non-English comic form but with pathetic, even psychological, overtones that anticipate a characteristically English one: the domestic tragedy of the turn of the century, which likewise deploys the traditional comic motifs of jealousy and cuckoldry in ways that develop a pathetic side. ${ }^{7}$ But it is in the later drama that the French impact on dramatic forms has most to tell us about inter-cultural connections. With regard to comedy and tragicomedy, given the acknowledged (if differently estimated) primacy in English of Italian models, both the commedia erudita and the commedia dell' arte, it seems judicious to speak of inflection by French intermediaries, an effect that hypothesizes, like all intertextual readings, a more-or-less distinct effect on a spectator's (or reader's) reception of a text against the background of established norms-cultural, structural, thematic, stylistic, etc.-a perception of "ungrammaticality," in Michael Riffaterre's terminology. ${ }^{8}$ According to those versions of intertextual theory that appear most critically functional, it is such a perception of anomaly that opens up the "elsewhere" where a text's perceived "incompleteness [may be] completed", according to a "travail de transformation et d'assimilation" (work of and assimilating), not necessarily of a single focused text, but potentially involving the effect on "plusieurs textes opéré par un texte centreur qui garde le leadership du sens" (several texts produced by a centring text which remains in charge of the meaning). ${ }^{10}$

7. Richard Hillman, Self-Speaking in Medieval and Early Modern English Drama: Subjectivity, Discourse and the Stage (Houndmills, Basingstoke, Hampshire: Macmillan, 1997), 94-98.

8. See esp. Michael Riffaterre, “The Interpretant in Literary Semiotics," American Journal of Semiotics 3.4 (1985): 41-55, and “Syllepsis," Critical Inquiry 6 (1980): 625-38.

9. Riffaterre, “Syllepsis," 627.

10. Laurent Jenny, “La Stratégie de la forme," Poétique 27 (1976): 257-81, 262; translations throughout are my own unless otherwise indicated. 
As an example highlighting cultural inflection, let me cite my proposition of several years ago that A Midsummer Night's Dream's generic innovation within English drama is made manifest, not only by its intra-textual deployment of the motifs of Arcadian amorous transformation made commonplace by Sannazaro, Sidney, Montemajor, Guarini (Il Pastor Fido), and Tasso (Aminta), but also by an intertextual attraction exercised by at least two generically charged French texts. ${ }^{11}$ Most immediately, the pastoral motifs in question had very recently been adapted in the La Diane of Nicolas de Montreux (pub. 1594), which presents both general and specific correspondences with A Midsummer Night's Dream. But that same year also saw the publication of Le Proumenoir de Monsieur de Montaigne, the only work of fiction by Marie de Gournay, which offers a distinctively feminist slant on the formulas of the histoire tragique. I have made the argument for the ironic inflection by that novel, and its tradition, of Shakespeare's comic trajectory to support his undercurrent of love turned tragically fatal, particularly for women as victims of male inconstancy. ${ }^{12}$ That is, after all, the issue focused in the story that Marie de Gournay insistently evokes as an intertext for her own-that of Theseus and Ariadne, which she imports by way of Catullus.

The elusive form of tragicomedy-so elusive that the compilers of the First Folio presumably chose to let it slip through their typological fingerspresents a particularly complex pattern, or patterns. Still, an argument can be made that representatives of the two main strands of the genre commonly socalled in early modern English drama carry French generic markers. Among Shakespeare's late plays, at least the collaborative Pericles, which occupies a chronologically pivotal position, and The Winter's Tale appear to take on a supplementary dimension by this route: the former through François de Belleforest's contemporary rendition of the Apollonius of Tyre story, which he actually labels a "tragi-comédie"; ${ }^{13}$ the latter by way of Montaigne's remarks

11. Richard Hillman, "A Midsummer Night's Dream and La Diane of Nicolas de Montreux," Review of English Studies 61.248 (2010): 34-54.

12. Richard Hillman, "Des Champs faëz de Claude de Taillemont au labyrinthe du Songe shakespearien, en passant par le Proumenoir de Monsieur de Montaigne," Studi Francesi 48.1 (2004): 3-18.

13. Richard Hillman, "Périclès, Belleforest et Apollonie de Tyr: quelques questions de source et de genre," in La Réception de lancien roman de la fin du moyen âge au début de lépoque classique: Actes du colloque de Tours, 20-22 octobre 2011, ed. Cécile Bost-Pouderon and Bernard Pouderon (Lyon: Maison de l'Orient et de la Méditerranée, 2015), 147-62. 
about imitating Ovid in connection with the near-death and virtual resurrection of Seneca's wife Paulina. ${ }^{14}$ As for the Fletcherian strain of tragicomedy, which one might be tempted to term erudita and which is famously distinguished by its adherence, following Guarini, to a generic synthesis that "wants deaths, which is inough to make it no tragedie, yet brings some near it, which is inough to make it no comedie,"15 this emerges against a French baroque backdrop, onstage and off-both narrative (conditioned chiefly by L'Astrée and Amadis de Gaule, the two as multiply translated and continued) and theatrical (beginning with Garnier's tragicomedy Bradamante [1582]), inspired by Ariosto's Orlando Furioso.

Whether or not one finds the label of tragicomedy useful in the case of All's Well That Ends Well, that play's stubborn positioning on the generic cusp within Shakespeare's oeuvre between comedy (in plot) and tragedy (in virtually every other respect) may be seen as combining, as regards French material, the principle of inflection with effects of reflection. The term "reflections"-and necessarily in the plural-appears especially useful with regard to early modern tragedies and history plays. It serves to indicate the resonances with French material of all kinds, ranging from self-consciously literary works to political, religious, and historical discourses, to which early modern English playwrights and audiences might reasonably have had access. Intertextuality allows for transformative effects along different planes, and if inflection may be imagined as exercising its effect along the vertical axis of genre, bending an established form out of recognized alignment, reflection may be envisaged as a horizontal

14. Richard Hillman, "Entre Shakespeare et Montaigne: quelque nouveaux tours d'escrime," in Shakespeare et Montaigne, vers un nouvel humanisme. Actes du congrès organisé par la Société Française Shakespeare en Oxford-Warburg Studies collaboration avec la Société Internationale des Amis de Montaigne, Paris, le 13, 14 et 15 mars 2003, ed. Jean-Marie Maguin and Pierre Kapitaniak (Paris: La Société Française Shakespeare, Institut du Monde Anglophone, Université de Paris III-Sorbonne Nouvelle, 2004), 135-53, 147-53.

15. John Fletcher, “To the Reader," in The Faithful Shepherdess, ed. Cyrus Hoy, vol. 3, The Dramatic Works in the Beaumont and Fletcher Canon, gen. ed. Fredson Bowers, 6 vols. (Cambridge: Cambridge University Press, 1966), 497. 
process, functioning as the linear experience of a given text triggers successive associations.

In the case of All's Well That Ends Well, I have proposed that a fundamental inflection would have operated for Shakespeare's audiences by way of their most immediate contemporary association of Roussillon, not with the setting of Boccaccio's original romance, territory then under the control of Philip II, but with the quite unrelated comté of Roussillon in the Dauphiné. ${ }^{16}$ The latter was well known to the English, thanks to diplomatic transactions involving, among others, Henry Carey, Lord Hunsdon (later the patron of the Lord Chamberlain's Men), and much in the news in the 1580s and 1590s as the scene of ultra-Catholic and Jesuit activity, centred on the university in Tournon. Prominent in contemporary discourses was the formidable widowed Countess of Roussillon (who has no equivalent in the "official" source story from Boccaccio's Decameron), as well as her son, who sustained the family tradition of military heroism.

But also in circulation must have been the romantically tragic story of the Countess's daughter Hélène, which intersects insistently both with All's Well and (by way of Ophelia) with Hamlet, a play that itself presents affinities with the problem comedy. Its diffusion was presumably due to the account in the Mémoires of Marguerite de Valois, though these would be published only later. The point is that this Hélène did not merely feign death, like Shakespeare's Helen (whom the Countess regards as a daughter) and her primary original (Boccaccio's Giletta), but actually died of a broken heart when rejected by the man she loved. Once romantic comedy is thus tragically inflected, multiple resonances with recent French history, notably involving the superficially heroic but pathetically futile wars of Italy, make themselves heard insistently in a way that compounds the generic instability of the play, adding depth in particular to the underside of the "happy" ending. That ending, after all—which has never seemed thoroughly to redeem the reprehensible jeune premier-depends on a double "miracle" (Helen's "resurrection" and pregnancy), which is all the more

16. On the aspects of All's Well touched on here, see Hillman, French Reflections, 150-90 (chapter 4). A roughly similar approach has since been proposed for the Navarre of Love's Labour's Lost as a multiply allusive setting by Elizabeth Pentland, "Shakespeare, Navarre, and Continental History," in Interlinguicity, Internationality, and Shakespeare, ed. Michael Saenger (Montreal and Kingston: McGillQueen's University Press, 2014), 23-45. 
clearly foregrounded, thanks to the French intertext, as contrived-that is, ultimately, as a self-reflexive function of comic convention.

To take up the generic line of the unambiguously tragic, the French reflections I have proposed for plays ranging from The Spanish Tragedy to Antony and Cleopatra tend, not surprisingly, to import political and religious issues, and they do so in a variety of ways. ${ }^{17}$ French neo-Senecan tragedy on classical themes takes on recognizably local political colouring-intimations of civil war and tyranny-even before the outbreak of the first War of Religion in 1562: witness Étienne Jodelle's Cléopâtre captive (performed 1553, published 1574) and the Latin Iulius Caesar of Jacques-Antoine Muret (performed 1546), adapted in French by Jacques Grévin (published 1561). These intimations were seconded by the deployment of neo-Senecan devices, motifs, and rhetoric. Such "French accents" feed into English neo-Senecan practice from the earliest experiments in the 1560s (Preston's Cambyses, Sackville and Norton's Gorboduc), then make themselves thoroughly at home in the late Elizabethan and early Jacobean treatments of classical themes. Regardless of specific borrowings, therefore-although many of these may be detected-it may be argued that, to a considerable extent, the political incisiveness of English tragedies on classical subjects is fundamentally a translation from the French.

There are also points of contact between the English stage and French tragedy more directly engagée, emanating from a theatre of propaganda whose extent and importance have arguably been underestimated (in part because of the relatively few surviving printed texts). Marlowe's The Massacre at Paris is a salient case in point, as is clear even from the text in its (no doubt) imperfect state. This is a case where the recent critical tendency to produce a protopostmodern exercise in cynicism by overriding distinctions between Marlowe's Huguenots and Catholics runs up against consistency in his treatment of highly

17. On these large questions, illustrated with specific examples, see Richard Hillman, French Origins of English Tragedy (Manchester: Manchester University Press, 2010), 33-61, and "The French Accents of Seneca on the Tudor Stage," in New Perspectives on Tudor Cultures, ed. Michael Pincombe and Zsolt Almásy (Newcastle: Cambridge Scholars Publishing, 2012), 244-62; see also Hillman, French Reflections, 94-118. 
charged intertexts, both dramatic and otherwise. ${ }^{18}$ Notably, Massacre inverts the discourses associated with the Admiral Coligny, the Duke of Guise, and Henri III in ultra-Catholic propaganda plays by François de Chantelouve (1575) and Pierre Matthieu (1589). ${ }^{19}$ Moreover, it includes, in its representation of the assassination of the Duke of Guise, an adaptation verging on partial translation of a French dramatic original: Le Guysien, by Simon de Belyard, published in $1592 .{ }^{20}$ This, too, is a product of propaganda on behalf of the Holy League, and again Marlowe engages it so as to turn its message back on the camp of its author. The parallel here depends on Belyard's onstage depiction of Guise's murder-a highly unusual dramatic procedure for French plays of the period-which is naturally presented as a martyrdom. The (inverted) parallel with the equivalent scene in Massacre is so close as to establish a new terminus a quo for the composition of Marlowe's play.

There are many less direct (and less distinct) reflections of contemporary religious controversy in Marlowe's Edward II. Indeed, the subject of this tragedy might seem to have been chosen so as to resonate with the prolific League propaganda of the late 1580s, which targeted Henri III at once as a tyrant and as a sexual degenerate. ${ }^{21}$ If the resonances with this propaganda are insistent, their ideological trajectory seems rather more obscure than in Massacre. It is clear, however, that the principle of the providential mutual destruction of evildoers present in contemporary Protestant representations of Henri III and his League enemies, and made all but explicit in Massacre, is effectively recycled in the ending. So is the emergence of a monarch resplendent with honest renewal

18. For examples of the distinction-blurring tendency, see Judith Weil, Christopher Marlowe: Merlin's Prophet (Cambridge: Cambridge University Press, 1977), 82-104, and Charles Nicholl, The Reckoning: The Murder of Christopher Marlowe (London: Jonathan Cape, 1992), 107.

19. See Richard Hillman, Shakespeare, Marlowe and the Politics of France (Houndmills, Basingstoke, Hampshire: Palgrave, 2002), 72-100, and “The Admiral Upside-Down, or Apocalypse Now and Then: Marlowe's The Massacre at Paris and Chantelouve's La tragédie de feu Gaspard de Colligny," in Les Huguenots dans les Îles britanniques de la Renaissance aux Lumières: Écrits religieux et représentations, ed. Anne Dunan-Page and Marie-Christine Munoz-Teulié, Vie des Huguenots 85 (Paris: H. Champion, 2008), 61-85.

20. See Richard Hillman, "Marlowe's Guise: Offending against God and King," Notes and Queries 55.2 (2008): 154-59.

21. On Edward II, see Hillman, Shakespeare, Marlowe, 97-111. 
and bent on righteous vengeance. That vengeance includes the emblematic expulsion of French corruption in the person of the French queen.

A similar configuration, mutatis mutandis, concludes The Troublesome Reign of John, King of England (1589-90), which is increasingly accepted as the work of George Peele. Peele's play reaches even further back into Plantagenet history, with its deep imbrication of English and French interests, in a way calculated to strike contemporary anti-Catholic chords: the oath-taking of the treasonous English nobles in service to a "holy knot of Catholic consent" (part 2, 3.200), a "holy League" (part 2, 3.217); the monk whose regicide is supposedly "meritorious" (part 2, 6.141). ${ }^{22}$ Marlowe's procedures in Massacre are also thereby anticipated. But especially remarkable in this context is the dampening of such resonances in Shakespeare's later, less blatantly partisanand certainly more pervasively cynical—version of the same events. ${ }^{23}$

The portrayal in English historical dramas of symbolically charged figures of nationhood is likewise capable of attracting contemporary French-English resonances with destabilizing results. Such resonances complicate, notably, the ultimate anti-English villain, Joan de Pucelle (in Henry VI, Part One), and the ultimate anti-French hero, Henry V (in Shakespeare's portrayal). The former would arguably have come into focus as less (or more) than a sorceress and a whore through the intertextual lens of Jeanne d'Arc's current symbolic appropriation in the cause of the House of Lorraine, chief sponsors of the League. That appropriation is evidenced by the first tragedy on the subject, published in 1581, L'histoire tragique de la Pucelle de Dom Rémy, by the Jesuit professor of rhetoric Fronton Du Duc. Fronton Du Duc was based at the university of Pontà-Mousson in Lorraine, an institution that actively promoted, among other

22. References are to George Peele, The Troublesome Reign of John, King of England, ed. Charles R. Forker, The Revels Plays (Manchester: Manchester University Press, 2011), and appear in parentheses in the main text.

23. See Hillman, Shakespeare, Marlowe, 58-63, and Richard Hillman, "Le devenir de la polémique autour du roi Jean dans le théâtre élisabéthain," in Théâtre et polémique religieuse, ed. Juan Carlos Garrott Zambrana, Regards croisés sur la scène européenne (Tours: Centre d'Etudes Supérieures de la Renaissance, 2014), http://www.umr6576.cesr.univ-tours.fr/publications/polemique/. 
ultra-Catholic causes, the interests of Mary, Queen of Scots. ${ }^{24}$ The work was evidently commissioned as a political act, and the history it presents is skewed accordingly, despite explicit and implicit claims to historicity. The latter include precise details concerning Jeanne's trial and execution at Rouen in 1431. Yet those events are mediated by a traditional, nationally-coded conflict, dating back at least to the late fifteenth-century Mistère du siège d'Orléans, between Jeanne and John Talbot, Earl of Shrewsbury, who in fact was in French captivity at the time of her trial. ${ }^{25}$

Such background throws into sharp focus the contrasting method of Henry VI, Part One (by Shakespeare in collaboration, putatively with Thomas Nashe). This consists in frankly privileging myth over reality by radically dislocating some historical facts (most flagrantly, Joan, executed in 1431, is made responsible for the death of Talbot at Castillon in 1453), and suppressing others (her well-documented trial, and indeed the significant context of Rouen as a locale). The method is pushed to the point where Joan herself becomes an unlocalized and disembodied symbol, less of French collaboration with diabolic forces than of the English inability to reckon with the devil of their own discord. That is, of course, the devil which they carry back to England after their French debacle-most immediately in the deceptively beautiful form of Marguerite d'Anjou, who in the staging conspicuously takes the place of Joan, but ultimately in the overtly monstrous one of Richard III.

Shakespeare's Henry $V$ also engages the ambiguity of its subject's mythical status, here as England's ultimate conqueror of France, by ostentatiously disengaging from history, in particular as recounted in Holinshed's Chronicle, which would have been generally familiar to the public. ${ }^{26}$ The subversive "French" aspersions surreptitiously cast on Henry's image include the skepticism recorded in the Chronicle regarding the Agincourt "miracle." They

24. See Hillman, Shakespeare, Marlowe, 130-52, and Fronton Du Duc, The Tragic History of La Pucelle de Domrémy, Otherwise Known as The Maid of Orléans, ed. and trans. Richard Hillman, Carleton Renaissance Plays in Translation 39 (Ottawa: Dovehouse Editions, 2005), 24-51.

25. See also Richard Hillman, "La Pucelle and the Godons in the Mistère du Siège d'Orléans: Civic Pageant and Popular Tradition," in Les Mystères: Studies in Text, Theatricality and Urban Drama, ed. Peter Happé and Wim Hüsken, Ludus: Medieval and Early Renaissance Theatre and Drama 12 (Amsterdam: Rodopi, 2012), 167-88.

26. On the Chronicle in relation to the play from this point of view, see Hillman, Shakespeare, Marlowe, $190-97$. 
become insistent, however, through the historical account of Henry's siege of Rouen in 1418-19-that is, within the chronological gap at once opened and (fore)closed in the play by the Chorus's evocatively vague reference to "All the occurrences, whatever chanc'd," ${ }^{27}$ between Agincourt (1415) and the king's last journey to France to conclude the Treaty of Troyes (1420). The Chronicle's account of this brutal siege, which was conspicuously short on miracles for either side, is substantial. As often, moreover, the multi-vocal structure of the Chronicles allows into play the perspective of the enemy; vividly evoked in this case are the gallantry of the defenders (in strong contrast with the play's picture of the French at Agincourt as vainglorious and cowardly), the pitiful suffering of the civilian populace, and Henry's casting of all responsibility upon the French themselves. The last point fits into a pattern pervasive in the play, beginning with the Archbishop of Canterbury's obligation to stake his soul on the justice of the king's cause: "The sin upon my head, dread sovereign!" (1.2.97).

French intertexts concerned with contemporary politics arguably bear more directly, if also ironically, on Shakespeare's version of the ultimate English conqueror of France. These include the insistent discourse of heroic yet humane conquest in a divinely supported cause that teemed from the Huguenot and English presses in support of Henri de Navarre's right to the French throne. ${ }^{28}$ The resonances with contemporary French hagiography problematize the crude nationalist binarism of the play, widening the internal fissures within its apparently absolute identification of Henry's cause with God's. And the fissures would gape all the more widely for an audience of 1599 looking back at the 1593 conversion to Catholicism of Protestantism's providential hero.

A case can also be made for the pertinence of a very recently published French compilation (probably the work of Simon Goulart) entitled (in its English translation of 1598), An historical collection, of the most memorable accidents, and tragicall massacres of France, vnder the raignes of Henry. 2. Francis. 2. Charles. 9. Henry. 3. Henry. 4. now liuing. ${ }^{29}$ There is material here

27. William Shakespeare, Henry V, in The Riverside Shakespeare, gen. eds. G. Blakemore Evans and J. J. M. Tobin, 2nd ed. (Boston: Houghton Mifflin, 1997), 5.Cho.40. With the (doubtful) exception of The Taming of a Shrew, Shakespearean references are to this edition.

28. See Lisa Ferraro Parmelee, Good Newes from Fraunce: French Anti-League Propaganda in Late Elizabethan England (Rochester, NY: University of Rochester Press, 1996), and Hillman, Shakespeare, Marlowe, 33-36, 188-90.

29. Hillman, French Origins, 9-11. 
bearing on depredations and church-robbing perpetrated by League partisans: a stolen "pyx" in that text resonates at once with an incident recorded in Holinshed and the "pax" for which Bardolph is hanged (3.6.40). And there are suggestive evocations, by way of the representation of the assassinated Duke of Guise as the "Caesar" of the League, of the Roman model ambiguously evoked for Shakespeare's Henry V (again in the key chorus introducing act 5). With the aid of a comparison to Marc Antony, the account in An historical collection echoes as well within the virtually contemporary tragedy of Julius Caesar, effectively translating from the French context a political question that haunts both Shakespearean plays: where is the line to be drawn between heroic leadership in a sacred cause and demagogic tyranny?

This discussion has now returned, by way of the English histories, to tragedies on classical themes. To what has already been said, I would first add a further parallel between contemporary French and English military strongmen which, for contemporary audiences, was liable to be evoked by the figure of Coriolanus. That the similarity between the sensational careers of Robert Devereux, Earl of Essex, beheaded for high treason in 1601, and Charles, duc de Biron, who suffered the same fate a year later, was current at the time is attested by pamphlets dating from 1602 (an English translation of an unknown French original) and 1607. The latter's partial title is Histoire de la vie et mort $d v$ Comte d'Essex avec vn discovrs grave et eloquent de la Royne d'Angleterre, au Duc de Biron sur ce subiect. La conspiration, prison, jugement, testament, et mort du Duc de Biron. Its date brings it close indeed to George Chapman's two-part dramatic treatment, The Conspiracy and Tragedy of Biron, which was staged (until censored following a complaint by the French ambassador) and published in 1608. Chapman actually incorporated Elizabeth's (historically founded) evocation of Essex as a means of admonishing Biron, who at the time was ambassador to England.

Chapman is also known for his substantial and varied translations of French material in three additional "French" tragedies. These pose large and fascinating questions of French-English transfer, which there is insufficient 
space to take up here. (I have made some attempts to do so elsewhere. ${ }^{30}$ ) A more succinct point concerning translation is made by the chronological coincidence of his Biron plays with the Coriolanus of Shakespeare and perhaps (though the dating is more conjectural) with the Coriolan of Alexandre Hardy. The latter tragedy has certainly been read as evoking the spectacular downfall of Biron, while Shakespeare's is regularly related to the career of Essex, who had explicitly been compared to Coriolanus in a Paul's Cross Sermon. ${ }^{31}$ Regardless of the indeterminate (if tantalizing) question of influence (in whichever direction) between the tragedies of Hardy and Shakespeare, the classical mediation of contemporary French-English political parallels emerges as a distinctive (if particularly complex) form of translation for, and by, the stage.

The case of Coriolanus brings into focus a broad question relating to cultural translation: how do English dramatic versions of familiar classical subjects-those that chiefly come to mind are Dido and Aeneas, Julius Caesar, and Antony and Cleopatra-relate to the French ones already in place? How does one assess the reflections of French precursors, in some cases more than one and themselves sometimes charged, in more or less indeterminate ways, with ideological baggage? In general, I would suggest that we step gingerly here and tease out local relations as they present themselves, waiting for a broader sample to emerge before drawing further conclusions. In a few cases-and more will undoubtedly be identified-we have close correspondences, even partial translations, to serve as guidelines. It can be shown that Samuel Daniel in his Cleopatra, which he presented to Mary Sidney Herbert as a complementary piece to her translation of the Marc Antoine of Garnier, actually incorporated

30. Richard Hillman, “The Tragic Channel-Crossings of George Chapman, Part I: Bussy D’Ambois and The Conspiracy and Tragedy of Byron," Cahiers Élisabéthains 65 (2004): 25-43, and “The Tragic ChannelCrossings of George Chapman, Part II: The Revenge of Bussy D'Ambois and The Tragedy of Chabot," Cahiers Élisabéthains 67 (2005): 23-31.

31. These points are documented in the introduction to my translation of Coriolan, online, accessed 19 July 2016, http://pufr-editions.fr/tei/390\#body.1_div1. On the intertextual relation between Coriolan and Coriolanus, see also Richard Hillman, "Tragedy as a Crying Shame in Coriolanus and Alexandre Hardy's Coriolan: The 'Boy of Tears' and the Hardy Boys," in Coriolan de William Shakespeare: Langages, Interprétations, Politique(s). Actes du Colloque international organisé à l'Université François-Rabelais les 3-4 novembre 2006 sous les auspices de la Société Française Shakespeare, ed. Richard Hillman (Tours: Presses Universitaires François-Rabelais, 2007), 175-94. 
bits and pieces of the Cléopatra captive in his own translation. ${ }^{32}$ (He used other fragments of it elsewhere, too.) It becomes far more difficult to sort out the verbal, dramatic, and thematic points that link Shakespeare's Antony and Cleopatra with Jodelle (whether directly or by way of Daniel), with Garnier (directly or by way of Mary Sidney Herbert), or with another less familiar treatment of the subject that appears to present particular intersections with Shakespeare-namely, the Cléopâtre of Nicolas de Montreux (1594?).

Montreux, previously mentioned as author of La Diane, was the courtpoet of Philippe-Emmanuel de Lorraine, duc de Mercœur, who held out for the Holy League in Brittany until 1598. It is even possible, given the uncertain date of Montreux's play, that the Countess's decision to translate Garnier, and to commission Daniel, was a response to Montreux's use of his heroic (and most improbably chaste) Egyptian heroine to glorify his patroness, the flamboyant and strong-willed wife of Mercœur, Marie de Luxembourg. (Such heroines held a special fascination for Montreux, who, in addition to a tragedy of Sophonisbe, also adapted an episode of the Orlando Furioso to produce a Tragédie d'Isabelle, which, in its presentation of the victim of the "More cruel" Rodomont, overlaps intriguingly, if very much in passing, with Othello. ${ }^{33}$ )

Relevant here may be the political role and personal relation with the Sidney family of Philippe de Mornay, seigneur du Plessis-Marly, the staunchly Protestant author of A Discourse of Life and Death, which the Countess chose as her play-translation's companion piece. Mornay had been a friend of Philip Sidney and continued to be close to the surviving brother, Robert. The latter was in Brittany as the queen's ambassador during the military expedition of John Norris against the League in 1593-94; at the same time, Mornay was the governor of Saumur charged with negotiating Mercœur's return to royal obedience. Such connections hint at translations at once political and literary that will probably defy our ability ever to decipher them fully.

32. The French-English dramatic and non-dramatic discourses bearing on representations of Cleopatra are extensively discussed in Hillman, French Reflections, 94-149 (chapter 3).

33. Nicolas de Montreux [Ollenix du Mont-Sacré], La tragédie d'Isabelle, in Le Quatrième livre des Bergeries de Julliette ... ensemble la tragédie d'Isabelle (Paris: G. Des Rues, 1595). See Hillman, French Origins, 76-77, and Richard Hillman, "L'héroïsme au féminin chez Shakespeare et Nicolas de Montreux," in Shakespeare, les Français, les France, ed. Ruth Morse, Cahiers Charles V 45 (Paris: Presses de l'Université Paris VII, 2009), 67-93. 
On the other hand, one non-dramatic translation from the French, more definitive but seemingly minor, turns out to bear on Shakespeare's Antony and Cleopatra in a surprisingly major way. The French translation of Plutarch's Lives by Jacques Amyot, itself the basis for Thomas North's English translation (1579), which Shakespeare famously echoes at a number of points, began to appear at least from 1583 as edited by the Geneva-based pastor and indefatigable manof-letters Simon Goulart (previously mentioned), a personage well known to Elizabethans. Of compelling interest here is a scathing marginal comment introduced in Goulart's edition of the Life of Marc Antony but absent from all editions of North's translation. In this remark, Goulart condemns Cleopatra's lamentations, her suicide, and her morals in uncompromising Calvinist terms: "En tous ces regrets on void la deplorable condition des personnes qui ne peuuent regarder plus loin que ceste vie. [...] On ne lit que desespoir \& desolation" (In all these regrets one sees the deplorable condition of persons who cannot see farther than this life. [...] One reads only despair and desolation). ${ }^{34}$

It seems beyond doubt that Shakespeare put into his Cleopatra's mouth a pointed refutation of this interpretation in a magnificent rephrasing of it: "My desolation does begin to make / A better life" (5.2.1-2). We have here precious "hard" evidence, or as hard as it can get, that the "Roman reading" of Cleopatra's character is not the full story according to Shakespeare, any more than is the case in the versions of Jodelle, Garnier, or Montreux. And we have a highly intriguing indication that, even when North's translation looms monolithically as Shakespeare's "official" source for most of his Roman material-and many verbal echoes are beyond question-his reading, whether for reasons of curiosity or practical access, sometimes extended to the French of Amyot. There is a tangential bibliographical lesson to be drawn from this neglected parallel: Amyot's French Plutarch as edited by Goulart is not an especially rare book-several French libraries hold multiple copies in more than one edition. It is not widely held elsewhere, however, and notably does not figure in the Folger collection.

34. Plutarch, Les Vies des hommes illustres ... translatees par M. Jacques Amyot, ... enrichies en cette derniere edition ... d'annotations morales en marge qui monstrent le profit qu'on peut faire en la lecture de ces histoires, ed. Simon Goulart ([Dijon]: Ieremie Des Planches, 1583), fols. 620v-21r. 
I have deliberately saved for penultimate consideration the French reflections bearing on Hamlet, because, like most aspects of that most richly reflective of play-texts, they are especially enigmatic and elusive, qualities that notoriously match its protagonist and complicate the nature of his personal tragedy, or tragedies. Still, it is possible to take as a starting point the long-standing preoccupation of Hamlet criticism with Montaigne's Essais, at least in the translation of Florio (pub. 1603). Shakespeare's acquaintance with the latter is decisively established, of course, if not necessarily by the many Hamletechoes detected or suspected (which require supposing his access to Florio's manuscript, as is hardly impossible), at least by a close parallel in The Tempest, which I will be discussing shortly. With regard to Hamlet, I would add a few probable points of contact to the traditional list, some of which tend to confirm that, again, Shakespeare sometimes consulted both the translation and the original. ${ }^{35}$ These parallels essentially develop one facet of the character-what may be termed the "philosophical" Hamlet-but the play also offers others, as criticism itself has long reflected. These may be roughly classified under the headings of the "political" and the "psychological" Hamlet, both of which equally gain depth from French intertexts. The latter are of very different kinds.

The rotten politics of Hamlet's Denmark, which issue in catastrophic mutual slaughter and domination by a foreign power, had a recent model in France's religious wars and, particularly, in the failure to act in a decisive and principled manner of Antoine de Bourbon, King of Navarre, a figure of continuing interest to Shakespeare's public as the husband of the legendary Protestant heroine, Jeanne d'Albret, and the father of Henri IV. There was an abundant discourse in circulation concerning these events, impelled by Huguenot interests and including specific details that resonate with the character of Hamlet. Still, this is a case, like others, where the risk must be taken-if the interpretative result appears to justify it—of filling in discursive lacunae from scraps of historical information that survive. Thus, for instance, it is on the record (including that of the English intelligence service) that Antoine de Bourbon, who had emerged as the best hope of French Protestants, was 
angling for election to the Danish throne as a stepping-stone to the imperial one. This was a futile political response to his frustration over the loss of most of his kingdom (to Spain) and the machinations against him of his French enemies. The matter came to a head-and in fact came to nothing, like most of Antoine's schemes-in 1561, the year before the outbreak of the first civil war. (In that conflict, the King of Navarre was killed almost immediately, in less than heroic circumstances and fighting on the Catholic side, having renounced his Protestant professions.) The associated manoeuvres and counter-manoeuvres were highly complex and secretive, and hence remain largely out of reach, but once the resonances with Hamlet's character and story are allowed into playand some remarkable ones can be documented-it seems worth adducing such information as may be deduced, or reasonably conjectured. The image of the French prince potentially accessible to Shakespeare's audience may thus be posited as an active intertext.

When it comes to the "psychological" Hamlet, by contrast, the key candidate for a French intertext is singular and concrete, its accessibility not in question: the same volume of Belleforest's Histoires tragiques that manifestly served as one of Shakespeare's sources also contained a sensational narrative concerning Gaston "Phoebus," Prince of Foix. The story concerns a tense family drama focusing on a hapless son divided in loyalty between his alienated father (Gaston) and mother. He becomes unwittingly involved in the murderous plotting of a wicked uncle (Charles, King of Navarre) and subsequently dies inadvertently at the hands of his father, who, though driven by vengeful fury, had not meant to kill him. This is obviously not a template that fits perfectly onto the source story of Amleth as it is recounted elsewhere in the collection, but the very disjunctions attract attention to the supplement it supplies from an intertextual point of view. To read the crudely heroic Danish narrative of crime and triumphant retribution through the lens of the story of Gaston and his sonand this is plausibly the way Shakespeare would have read it-is to superimpose a family dynamic of alienated affection, jealousy, and vengefulness that issues in tragedy neither philosophical nor political, but intensely psychological. It is also intertextually to lend the ghost of Old Hamlet-not present in Belleforest's narrative - a paradoxical destructive power, as intuited also by Shakespeare's protagonist, over his hapless son. Both sons are effectively sacrificed to a ferocious paternal revenge of which they are not the objects-ironically, at the expense of their fathers' symbolic survival in this world. 
It is particularly instructive to end this survey of some varied forms of French "translation" that made their way onto the early modern English stage, or into the coulisses, by citing two cases of literal and flagrant, though fragmentary, translation. These focus the question that has been hanging over this modest survey from the outset: to what extent are critical theory and practice up to the challenge of (or indeed interested in) pursuing the interpretative implications of even the most evident English-French connections? For in certain cases where the basic facts have long been recognized, criticism has shown itself uncertain what to do with them, if anything.

This is clear, first, from discussions of the borrowing from Montaigne in The Tempest, which for years has been documented in major editions, although new precision has recently been brought to bear. At issue is the substantial passage (2.1.148-69) in which Gonzalo, against a counterpoint of mockery by Antonio and Sebastian, evokes a utopian "commonwealth" in terms obviously deriving from Montaigne’s "Des Canibales," ${ }^{6}$ at least in Florio’s translation ("Of the Cannibals"). It is not surprising that mere recognition of this allusion has not had a decisive impact on interpretation of the play, since the passage remains provocatively ambiguous in its context: what an audience makes of Gonzalo's utopianism and the baggage of "soft primitivism" it carries from Montaigne's essay will inevitably be bound up with a "soft" or "hard" reading of the play as a whole - and hence, ultimately, of Prospero. Yet even when the borrowing is pursued as an object of enquiry, it does not seem to have generated a genuinely intertextual dynamic-one that would enquire into an audience's response to a perception of discursive otherness. ${ }^{37}$ Arguably, two recent engagements with the phenomenon also bypass this challenge.

Kenji Go has usefully "revisited" the borrowing itself and, partly by way of some long-neglected observations of earlier scholars, has finely analyzed its composition, showing that Shakespeare amalgamated several passages

36. Book 1, chapter 30, in Les Essais de Michel de Montaigne: Édition conforme au texte de l'exemplaire de Bordeaux avec les additions de lédition posthume, etc., ed. Pierre Villey et V.-L. Saulnier, rev. ed. (Paris: Presses Universitaires de France, 1978).

37. As distinct from cultural otherness, which has naturally emerged as a topic by way of Montaigne; for a nuanced recent treatment, see Hassan Melehy, The Poetics of Literary Transfer in Early Modern France and England (Farnham: Ashgate, 2010), 237-55 (chapter 12). 
from the key essay. ${ }^{38}$ Go's discussion then shifts, however, to familiar concrete questions-the origin of the name Sycorax, the location of the island-on which the essay bears less forthrightly. The argument is thereby recentred on measuring the influence of the French author on the English one.

By contrast, the impressively erudite approach of Warren Boutcher, in The School of Montaigne in Early Modern Europe, is expansive, traversing a number of intertexts, notably Samuel Daniel's court entertainment, The Qeenes Arcadia (1605), which is shown to have quite specifically anticipated Shakespeare's borrowing, as well as to have borrowed in other respects from the French author. ${ }^{39}$ These facts serve to bolster Boutcher's overall argument-namely, that the cultural reception of Florio's Montaigne was important "in the formation of the liberty of judgement of the elite, the resolution of their emotional and political needs, and the constant reformulation of their family strategies in very uncertain moral, political, and dynastic circumstances." ${ }^{30}$ This centrifugal approach produces a centripetal counter-movement. As Boutcher reads his thesis back into the text, Gonzalo emerges as a well-intentioned but naive commentator on a key theme: the representation of "power both to enfranchise and to enslave." ${ }^{41}$ The fact remains that it is Prospero who wields such power, and that he does so in flagrantly ambiguous ways. Thus, even this positioning of the key textual echo within a complex social and political discursive context finally resolves into a traditional interpretative crux that does not depend on, or thoroughly take account of, the translating power of the intertext as such. Using an intertext to identify-or indeed to lend point and depth to-a theme does not put the intertext itself into productive play as such.

38. Kenji Go, “Montaigne's 'Cannibals' and The Tempest Revisited," Studies in Philology 109.4 (2012): 455-73.

39. Warren Boutcher, The Reader-Writer, in The School of Montaigne in Early Modern Europe, 2 vols. (Oxford: Oxford University Press, 2017), 1:258-71. On Daniel as intermediary, see also William M. Hamlin, Montaigne's English Journey: Reading the Essays in Shakespeare's Day (Oxford: Oxford University Press, 2013), 82-84.

40. Boutcher, 271.

41. Boutcher, 265. 
My final case in point is far more obscure, but it has also been on the scholarly books long enough to permit an assessment of its impact, or lack thereof. It happens also to be the case that launched my interest in French-English intertexts. In attempting-vainly-to settle the vexed question of priority between the anonymous play, The Taming of a Shrew, and the comedy of Shakespeare that obviously stands in a close relation to it, I stumbled some thirty years ago on the fact that the concluding speech in which the "shrew" declares her duty of marital submission was translated from the account of the divine order of the universe in La Création du monde by Guillaume Salluste Du Bartas-a poet enormously popular in England, of course, at least in part because of his Protestantism. I was not the first to have so stumbled: the New Cambridge Shakespeare editor of A Shrew, Stephen Roy Miller, who (wrongly, in my view) judges the play to be an acting version derived from Shakespeare's original, documents the borrowing itself and the history of its perception. ${ }^{42}$ What he conspicuously does not do, however, is put the French intertext to work by pursuing the ambiguous implications of its presence.

The equivalent passage in Shakespeare's The Taming of the Shrewprominent as the key to reading Katerina's "taming," hence to interpreting the play as a whole-has her evoking the submissive duty of the wife in terms of feudal obligation, but the sanction of divinity and the natural order of things is absent-conspicuously so, in light of the intertext. This point can be connected with suggestions elsewhere that Shakespeare's Petruchio imposes himself on Katerina problematically as the re-creator of the universe in which she must henceforth dwell, one in which time is at his command ('It shall be what a' clock I say it is" [4.3.195]) and the sun and the moon change places according to his quasi-divine word:

Then God be blest, it is the blessed sun,

But sun it is not, when you say it is not;

And the moon changes even as your mind.

42. William Shakespeare (attrib.), The Taming of a Shrew: The 1594 Quarto, ed. Stephen Roy Miller, The New Cambridge Shakespeare (Cambridge: Cambridge University Press, 1998), note to 14.116-25. 
What you will have it nam'd, even that it is,

And so it shall be so for Katherine. (4.5.17-21)

From this point of view, Katherina's shrewishness is foregrounded as a threat to the patriarchal order as established, not directly by God, but by God in Petruchio.

My point here lies, not in these arguments themselves, ${ }^{43}$ but in the fact that neither they nor their interpretative implications enter into Miller's discussion, although he notes that the anonymous translator suppressed Du Bartas's Platonically-tinged presentation of chaos as a precursor of the divine creation..$^{44}$ (This was a theologically sensitive question, as is shown by contemporary attacks and a defensive commentary supplied by-yet again-Simon Goulart. ${ }^{45}$ ) It appears artificial, in the face of such an insistent intertextual invitation, to maintain a traditional separation between editorial and critical approaches. Perhaps especially if we happen to be dealing with a derivative text adapted for performance, the sheer stubborn ("ungrammatical") presence within it of the translated intertext surely calls for attention in terms of the potential significance for audiences or readers-the site of the intertextual experience.

Two explanations, implying two contrasting intertextual effects, seem possible for the disjunctive parallel between the two plays. If Shakespeare's comedy is the revision, then his pointed suppression of the divine justification for female subordination would foreground Petruchio's usurpation of divine prerogative, virtually as a form of blasphemy. If, on the other hand, A Shrew were the derivative text (again, I remain skeptical), it might be that the revisor casually botched-up the concluding speech by translating a passage about creation that he (probably not she) remembered-a suggestive fact in itself. Alternatively, he (probably not she) might just have perceived the profoundly subversive implications of Shakespeare's precursor and sought to render it

43. They are set out in Richard Hillman, "La Création du monde et The Taming of the Shrew: Du Bartas comme intertexte," Renaissance and Reformation/Renaissance et Réforme 15.3 (1991): 249-58, and Shakespearean Subversions: The Trickster and the Play-Text (London: Routledge, 1992), 24-38.

44. Miller, ed., 150.

45. Simon Goulart, A learned summary upon the famous poeme of William of Saluste Lord of Bartas, etc., trans. T. L. D.M.P. [Thomas Lodge] (London: [George Purslowe] for Iohn Grismand, 1621), 16 (originally published as a commentary on the 1582 edition). 
resonantly anodyne. One way or the other, as spectators might also have noticed, the effect required omitting those lines of Du Bartas that come in their due place in the story of creation (the sixth day), where woman is glorified as man's indispensable, indeed redemptive, God-given helpmeet. ${ }^{46}$ And when selective translation of a well-known text is evident, entailing measurable distortion, intertextuality is engaged in a particularly complex way.

As is often true in working with Shakespearean sources and analogues, whatever the theoretical premise, there are too many textual and contextual uncertainties involved in this case to pronounce definitively as to cause or effect. But for our immediate purposes, what may be most helpful is the reminder that even where translation is precisely at issue in the most literal sense, a dramatic dynamic may result that proliferates meanings beyond any notion of a controlling original. Not to pursue those meanings, however tentatively, is to forfeit a signal opportunity for drawing closer to the conditions of textual production, a process that is inevitably, in both theory and practice, intertextual.

46. Guillaume de Salluste, seigneur Du Bartas, La Première sepmaine, in The Works of Guillaume de Salluste Sieur du Bartas, ed. Urban Tigner Holmes, Jr., John Coriden Lyons, and Robert White Linker, 3 vols., vol. 2 (Chapel Hill: University of North Carolina Press, 1938), 6.949-87 et passim. 
